\title{
The comparison of arthroscopic acromioplasty with and without acromioclavicular coplaning
}

\author{
Nuri Aydın, M.D., ${ }^{1}$ Barış Kocaoğlu, M.D., ${ }^{2}$ Ender Sarıoğlu, M.D., ${ }^{2}$ Okan Tok, M.D., ${ }^{3}$ Osman Güven, M.D. ${ }^{2}$
}

${ }^{1}$ Department of Orthopaedic and Traumatology, İstanbul University Cerrahpaşa Faculty of Medicine, İstanbul-Turkey

${ }^{2}$ Department of Orthopaedic and Traumatology, Acıbadem Kadiköy Hospital, İstanbul-Turkey

${ }^{3}$ Department of Orthopaedic and Traumatology, Lütfiye Nuri Burat State Hospital, İstanbul-Turkey

\begin{abstract}
BACKGROUND: Coplaning means the removal of medial acromial spurs and inferior aspect of the distal clavicle. The aim of the study was to evaluate the outcomes of arthroscopic acromioplasty with and without coplaning in patients without acromioclavicular (AC) joint arthritis.

METHODS: Because of impingement syndrome, arthroscopic subacromial decompression and acromioplasty was performed in Group I ( 9 males/3I female). In addition, coplaning was performed in Group 2 ( 8 males/2I females) by two different surgeons. The mean age was 48 in Group I, 46 in Group 2. The mean follow-up was 50 months and 44 months, respectively.

RESULTS: Constant score, cross-body adduction test and AC joint tenderness was used for follow-up. The mean preoperative Constant scores were 45 points (range: 34-76 points) in Group I, 39 points (range: 32-69 points) in Group 2. The mean Constant scores at the latest follow-up was 78 points (range: 68-100 points) for Group I, 84 points (range: $72-100$ points) for Group 2. There was no statistically difference between two groups at the latest follow-up $(p<0.05)$. In two patients in Group 2 , cross-body adduction test was positive but asymptomatic.
\end{abstract}

CONCLUSION: Excision of the inferior side of the lateral clavicle to the level of the acromion with minimal disruption of the joint capsule does not develop AC joint symptoms in long-term follow-up.

Keywords: Acromioclavicular joint; acromioplasty; arthroscopy; coplaning; impingement; shoulder.

\section{INTRODUCTION}

The subacromial impingement syndrome of the shoulder is treated with acromioplasty and subacromial decompression. [1] The frequency of this procedure has increased dramatically in the last decade. ${ }^{[2,3]}$ Subacromial decompression, described by Neer, includes acromioplasty, division of the coracoacromial ligament, and excision of the inferior spurs of the distal clavicle. Outlet impingement typically begins at the anteroinferior aspect of the acromion and progress medially to involve the acromioclavicular (AC) joint. ${ }^{[4,5]}$ After acromioplasty, an abrupt step-off may be formed between acromion and distal end of the clavicle, which may behave like a spur. Distal clavicle coplaning was advocated in the original descriptions of arthro- scopic subacromial decompression. ${ }^{[6-9]}$ Coplaning means the removal of the inferior side of the distal clavicle. Previous studies have reported that the disruption of the AC joint increased joint mobility, suggesting that this would lead to AC joint pain. ${ }^{[10,11]}$ Spurs located at the inferior aspect of the joint were shown to be associated with rotator cuff pathologies. ${ }^{[12]}$ This asymptomatic, coincidental situation is treated by most shoulder surgeons by coplaning at the end of the arthroscopic acromioplasty procedure. There is no enough data in the published literature regarding the results of coplaning procedure with minimal disruption of the joint capsule.

The aim of this study was to compare two groups of patients who were operated with an arthroscopic acromio-

Cite this article as: Aydın N, Kocaoğlu B, Sarığlu E, Tok O, Güven O. The comparison of arthroscopic acromioplasty with and without acromioclavicular coplaning. Ulus Travma Acil Cerrahi Derg 2018;24:274-277.

Address for correspondence: Nuri Aydın, M.D.

İstanbul Üniversitesi Cerrahpaşa Tıp Fakültesi, Ortopedi ve Travmatoloji Anabilim Dalı, Fatih, İstanbul, Turkey

Tel: +90 212 - 4143000 E-mail: nuri.aydin@istanbul.edu.tr

Ulus Travma Acil Cerrahi Derg 2018;24(3):274-277 DOI: 10.5505/tjtes.2017.61I78 Submitted: 24.07.2017 Accepted: 19.09.2017 Online: 08.05.2018

Copyright 2018 Turkish Association of Trauma and Emergency Surgery 
plasty with and without coplaning in patients without $A C$ arthritis.

\section{MATERIALS AND METHODS}

A retrospective review of the surgical database was performed to detect all patients operated with impingement syndrome. The surgical data was collected from the patient files. The patients who had shoulder impingement with chronic symptoms were included in the study. There were 69 patients, including 17 men and 52 women with a mean age of 48 years (range: 29-66 years). All patients underwent plain radiography and $M R$ imaging of the shoulder. The inclusion criteria were a positive Neer's test, type-II or type-III acromion shape; pain in the shoulder which was non-responsive to immobilization, anti-inflammatory drugs, subacromial steroid injections, and physiotherapy; and symptoms persisting for $>3$ months. All patients had thus been treated with physical therapy at their primary hospital or at our institution. This included exercise programs, massage, heat, and transcutaneous nervous stimulation. The patients with history of glenohumeral surgery, acromioplasty with rotator cuff repairs, AC joint arthritis, labral tears, rotator cuff with fatty infiltration, intraarticular biceps tendon pathologies, and arthritis were excluded. The surgeries were performed by two surgeons. Patient groups were assigned by the surgeon. Surgeon A was routinely not performing coplaning in acromioplasty cases (Group I). Surgeon B was performing coplaning in acromioplasty cases. The review of the surgical data resulted with the classification of the patients into two groups. Group I included the patients with acromioplasty alone and Group 2 included the patients with acromioplasty and coplaning.

During the surgery, surgical field was palpated and the bony structures were marked with a sterile pen. Surgery was performed under general anesthesia. All operations were performed with the patient in the beach chair position. The scope was placed through the posterior portal and a systematic evaluation of intraarticular structures was performed. The same standard portal was used to access the subacromial space. Debridement and decompression were performed through an anterolateral portal by radiofrequency probe (Starvac 90, ArhroWand, Arthrocare, Texas, USA). Acromioplasty was performed using an oval burr; the resection of the lateral acromion starting anteriorly was performed first, followed by the resection of the medial acromion extending up to the $A C$ joint. Range of motion of the shoulder was evaluated under arthroscopic visualization to check for any local impingement. Bone resection was performed to remodel type-II or type-III acromion to a type-I acromion. In the Group I, no coplaning was performed (Fig. I). In the Group 2, the inferior side of the lateral clavicle was excised to the same level of the acromion with minimal disruption of the joint capsule (Fig. 2). A sling was used for a week, and mobilization was permitted with free active movements, starting with gravity-assisted rotation movements as pendulum exercises. Following this, pa-
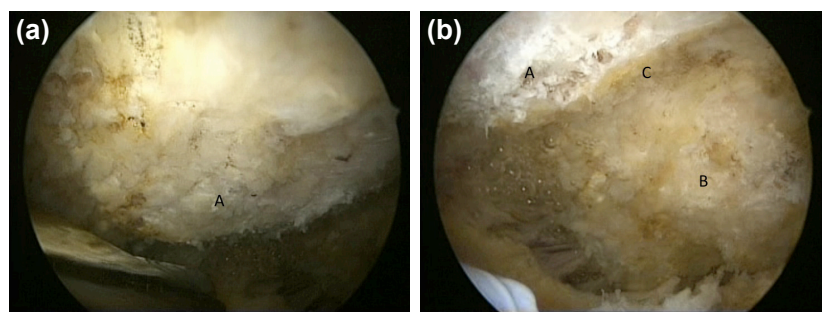

Figure 1. (a) The scope is at the posterior portal: Before the acromioplasty of type-III acromion. (A) Acromion. (b) After performing acromioplasty. (A) Acromion after resection, (B) Distal end of the clavicle without coplaning, (C) Acromioclavicular joint.
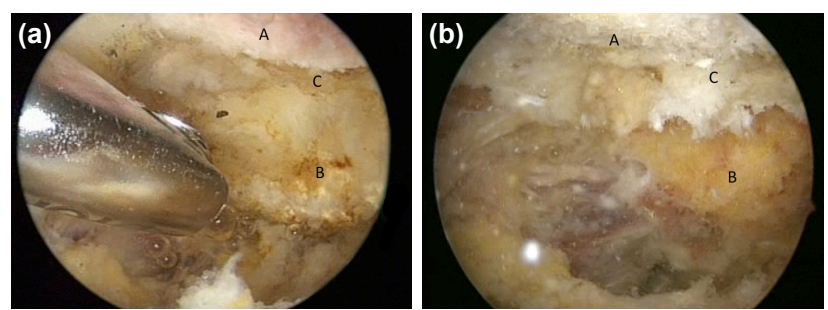

Figure 2. (a) After performing acromioplasty. (A) Acromion after resection, (B) Distal end of the clavicle before coplaning, (C) Acromioclavicular joint. (b) After the acromioplasty and coplaning. (A) Acromion after resection, (B) Distal end of the clavicle after coplaning, (C) Acromioclavicular joint.

tients received personalized, progressive exercise programs. The patients were followed-up with Constant scores. At the final examination, AC joint tenderness and cross-body adduction test was performed to test for any $A C$ joint issues.

The t-test was used to compare the differences between preoperative and postoperative Constant scores in both groups. All statistical analyses were performed by an independent statistician using SPSS II.0 software (SPSS Inc.). The significance level was set at $\mathrm{p}=0.05$.

Ethical clearance for this study was provided by Acıbadem University Medical Research and Evaluation Board.

\section{RESULTS}

Group I included of 40 patients ( 9 men and 31 women). The mean age was 48 years (range: $28-60$ years). The mean follow-up duration was 50 months (range: 26-70 months). Group 2 had 29 patients ( 8 men and 21 women). The mean age was 46 years (range: 29-63 years). The mean follow-up was 44 months (range: $24-66$ months).

The mean preoperative Constant scores were 45 points (range: 34-76 points) in Group I and 39 points (range: 32-69 points) in Group 2. The mean Constant scores at the latest follow-up was 78 points (range: 68-100 points) for Group I and 84 points (range: 72-100 points) for Group 2. There was no statistically significant difference in mean Constant scores between two groups at the latest follow-up ( $p>0.05)$. No patients had AC joint symptoms in Group I. Mild pain 
was detected in cross-body adduction test in two patients in Group 2. In these two patients, there was no joint pain or tenderness around. One patient in Group 2 had fracture of the distal end of the clavicle with intra-articular extension after a fall at home. Complete removal of the AC joint was performed arthroscopically in a second operation.

\section{DISCUSSION}

Excision of the inferior side of the distal end of the lateral clavicle to the level of the acromion with minimal disruption of the joint capsule does not result in AC joint symptoms in long-term follow-up. After the removal of the anterior acromion, a visible step between the resected area and the lateral clavicle may occur. This step may behave like a spur. Petersson et al. ${ }^{[12]}$ showed that coplaning would decrease the pressure on supraspinatus tendon and muscle by this step created by the acromioplasty.

Klintberg et al. ${ }^{[13]}$ have reported satisfactory results in patients treated with arthroscopic subacromial decompression in long-term follow-up. When the arthroscopic acromioplasty is performed, the $\mathrm{AC}$ joint could be disrupted to some extent unless the resection of the acromion stops short of the medial end of the acromion. ${ }^{[14]}$ The common finding is that the coplaning may disrupt the AC joint capsule and the joint may become unstable. ${ }^{[6,8,15-18]}$ Resection of a big portion of the joint capsule may likely result in increase of the movement. Destabilization of the AC joint would make it possible for future arthritis of the joint with symptoms. ${ }^{[5,19]}$ Human cadavers which various arthroscopic procedures performed were evaluated. ${ }^{[20]}$ It was shown that the resection of $25 \%$ of the $A C$ joint increased joint range of motion. Elevation and rotation of the lateral clavicle were the significant movements. It is also well known that a total resection of the lateral clavicle may result in the destabilization of the whole clavicle. ${ }^{[19]}$ Another study by $\mathrm{Kim}^{[4]}$ showed that excision of the distal clavicle combined with rotator cuff repair for asymptomatic AC joint arthritis has lower functional scores because of temporary pain in the early postoperative period, but better functional outcomes with satisfactory pain relief and no reoperation rate were observed after 2 years.

A retrospective study on coplaning in connection with subacromial decompression did not report these issues. ${ }^{[1]}$ In Weber's study, the lateral joint capsule was observed to include $25 \%$ of the medial acromial side, with some osteophytes located on the medial acromion. This means that it is not possible to perform acromioplasty, as it is commonly thought, without joint capsule damage. The review of 1259 arthroscopic acromioplasties with a follow-up was 7 years, three patients were undergone total removal of the lateral clavicle. In this study, the medial aspect of the acromion was resected. In addition, the joint capsule was damaged. Any visibly prominent inferior portion of the lateral clavicle beyond the level of the medial acromion was removed. The impor- tant surgical point is that the articular cartilage of the $A C$ joint was not damaged. However, in the recent study, the cartilage was disrupted. But this was not shown with an increase in $A C$ joint pain. Weber stated that if a significant portion of the joint is not damaged, it will not result in $A C$ joint pain. [14,19,21] The clinical evaluation of AC joint motion is a simple and trustworthy method to assess the clinical results. ${ }^{[22]}$

Our findings are similar to Weber's findings. In two patients, pain was seen in cross-body adduction test at long-term follow-up without any joint symptoms. A patient in the coplaning group had a distal clavicle fracture after a fall at home. Coplaning might have led to weakening and mechanical failure of the bone. The most common two causes for persistent pain after acromioplasty are the failure of diagnosis and surgical technique. The common surgical issue associated with arthroscopic acromioplasty is inadequate bone excision. ${ }^{[14,23-}$ ${ }^{25]}$ It is shown that $23 \%$ patients still have a hooked acromion after acromioplasty. ${ }^{[25]}$

The study has some limitations. The first, only Constant score, which is not specific for AC joint, was evaluated during follow-up evaluations. The second is the varying preoperative management in the patients. All patients in the study received preoperative physiotherapy in their primary hospital or in our institution. Hence, the patient group was not standardized for preoperative physical therapy. Some patients were referred to clinics to other institutions. That is why we could not manage to have them in our physical rehabilitation department to have the same postoperative rehabilitation protocol.

Overall, without enough coplaning of the distal inferior portion of the lateral clavicle and spur of the acromion, the supraspinatus tendon becomes tight; the long-term consequences of this on rotator cuff anomalies might not manifest for years. ${ }^{[14]}$

\section{Conclusion}

Although the coplaning of $A C$ joint might influence $A C$ joint motion, it is unclear if these effects are clinically relevant. Excision of the inferior side of the distal end of the lateral clavicle to the level of the acromion with minimal disruption of the joint capsule does not lead to AC joint symptoms in long-term follow-up.

\section{Conflict of interest: None declared.}

\section{REFERENCES}

1. Neer CS 2nd. Anterior acromioplasty for the chronic impingement syndrome in the shoulder: a preliminary report. J Bone Joint Surg Am 1972;54:41-50. [CrossRef]

2. Papadonikolakis A, McKenna M, Warme W, Martin BI, Matsen FA 3rd. Published evidence relevant to the diagnosis of impingement syndrome of the shoulder. J Bone Joint Surg Am 2011;93:1827-32. [CrossRef] 
3. Mauro CS, Jordan SS, Irrgang JJ, Harner CD. Practice patterns for subacromial decompression and rotator cuff repair: an analysis of the American Board of Orthopaedic Surgery database. J Bone Joint Surg Am 2012;94:1492-9. [CrossRef]

4. Kim J, Chung J, Ok H. Asymptomatic acromioclavicular joint arthritis in arthroscopic rotator cuff tendon repair: a prospective randomized comparison study. Arch Orthop Trauma Surg 2011;131:363-9. [CrossRef]

5. Chen AL, Rokito AS, Zuckerman JD. The role of the acromioclavicular joint in impingement syndrome. Clin Sports Med 2003;22:343-57.

6. Altchek DW, Carson EW. Arthroscopic acromioplasty: indications and technique. Instr Course Lect 1998;47:21-8.

7. Caspari RB, Thal R. A technique for arthroscopic subacromial decompression. Arthroscopy 1992;8:23-30. [CrossRef]

8. Ellman H. Arthroscopic subacromial decompression: analysis of one- to three-year results. Arthroscopy 1987;3:173-81. [CrossRef]

9. Ellman H, Kay SP. Arthroscopic subacromial decompression for chronic impingement. Two- to five-year results. J Bone Joint Surg Br 1991;73:395-8. [CrossRef]

10. Blazar PE, Iannotti JP, Williams GR. Anteroposterior instability of the distal clavicle after distal clavicle resection. Clin Orthop Relat Res 1998:114-20. [CrossRef]

11. Edwards SG. Acromioclavicular stability: a biomechanical comparison of acromioplasty to acromioplasty with coplaning of the distal clavicle. Arthroscopy 2003;19:1079-84. [CrossRef]

12. Petersson CJ, Gentz CF. Ruptures of the supraspinatus tendon. The significance of distally pointing acromioclavicular osteophytes. Clin Orthop Relat Res 1983:143-8.

13. Klintberg IH, Svantesson U, Karlsson J. Long-term patient satisfaction and functional outcome 8-11 years after subacromial decompression. Knee Surg Sports Traumatol Arthrosc 2010;18:394-403. [CrossRef]
14. Barber FA. Long-term results of acromioclavicular joint coplaning. Arthroscopy 2006;22:125-9. [CrossRef]

15. Fischer BW, Gross RM, McCarthy JA, Arroyo JS. Incidence of acromioclavicular joint complications after arthroscopic subacromial decompression. Arthroscopy 1999;15:241-8. [CrossRef]

16. Hazel RM, Tasto JP, Klassen J. Arthroscopic subacromial decompression (A 9-year follow-up). Arthroscopy 1998;14:419.

17. Kuster MS, Hales PF, Davis SJ. The effects of arthroscopic acromioplasty on the acromioclavicular joint. J Shoulder Elbow Surg 1998;7:140-3.

18. Esenyel CZ, Oztürk K, Bülbül M, Ayanoğlu S, Ceylan HH. Coracoclavicular ligament repair and screw fixation in acromioclavicular dislocations. Acta Orthop Traumatol Turc 2010;44:194-8. [CrossRef]

19. Barber FA. Coplaning of the acromioclavicular joint. Arthroscopy 2001;17:913-7. [CrossRef]

20. Roberts RM, Tasto JP, Hazel MH. Acromioclavicular joint stability after arthroscopic coplaning. In: 17th Annual Meeting of the Arthroscopy Association of North America: 1998 Apr 30-May 3; Orlando, Florida. [Abstracts]

21. Weber SC:Coplaning the acromioclavicular joint at the time of acromioplasty (A long-term study). Arthroscopy 15:555, 1999.

22. Motta P, Bruno L, Maderni A, Tosco P, Mariotti U. Acromioclavicular motion after surgical reconstruction. Knee Surg Sports Traumatol Arthrosc 2012;20:1012-8. [CrossRef]

23. Connor PM, Yamaguchi K, Pollock RG, Flatow EL, Bigliani LU. Comparison of arthroscopic and open revision decompression for failed anterior acromioplasty. Orthopedics 2000;23:549-54.

24. Hawkins RJ, Chris T, Bokor D, Kiefer G. Failed anterior acromioplasty. A review of 51 cases. Clin Orthop Relat Res 1989:106-11.

25. Ogilvie-Harris DJ, Wiley AM, Sattarian J. Failed acromioplasty for. impingement syndrome. J Bone Joint Surg Br 1990;72:1070-2. [CrossRef]

\section{ORIJIINAL ÇALIŞMA - ÖZET}

\section{Akromiyoklaviküler eşplanlama yapılan ve yapılmayan artroskopik akromiyoplastilerin karşılaştırılması \\ Dr. Nuri Aydın, ${ }^{1}$ Dr. Barış Kocaoğlu, ${ }^{2}$ Dr. Ender Sarıoğlu, ${ }^{2}$ Dr. Okan Tok, ${ }^{3}$ Dr. Osman Güven ${ }^{2}$}

${ }^{1}$ İstanbul Üniversitesi Cerrahpaşa Tıp Fakültesi, Ortopedi ve Travmatoloji Anabilim Dalı, İstanbul

${ }^{2}$ Acıbadem Kadıköy Hastanesi, Ortopedi ve Travmatoloji Kliniği, İstanbul

${ }^{3}$ Lütfiye Nuri Burat Devlet Hastanesi, Ortopedi ve Travmatoloji Kliniği, İstanbul

AMAÇ: Eşplanlama medial akromiyal spurların ve distal klavikulanın alt kısmının çıkarılması demektir. Bu çalısmanın amacı, akromiyoklaviküler artrit olmayan hastalarda, eşplanlama uygulanan ve uygulanmayan artroskopik akromiyoplasti tedavisi yapılan hastaların değerlendirilmesidir.

GEREÇ VE YÖNTEM: Sıkışma sendromu nedeniyle, Grup I'deki hastalara (9 erkek/3I kadın) artroskopik subakromiyal dekompresyon ve akromiyoplasti uygulandı. Aynı endikasyon ile Grup 2'deki hastalara (8 erkek/2। kadın) Grup I'deki tedaviye ilave olarak eşplanlama uygulandı. Ortalama yaş, Grup I'de 48, Grup 2'de 46 idi. Ortalama takip süresi sırasıyla 50 ay ve 44 ay idi.

BULGULAR: Takipte Constant skoru, çapraz addüksiyon testi ve akromiyoklaviküler hassasiyet kullanıldı. Ortalama ameliyat öncesi Constant skoru Grup I'de 45 (aralık: 34-76), Grup 2'de 39 (aralık: 32-69) olarak bulundu. En son takipte ortalama Constant skorları Grup I için 78 (aralık: 68-100 puan), Grup 2 için 84 (aralık: $72-100$ puan) olarak bulundu. En son takipte iki grup arasında istatistiksel olarak anlamlı fark yoktu ( $p<0.05)$. Grup 2'deki iki hastada, çapraz addüksiyon testi pozitif fakat semptomsuzdu.

TARTIŞMA: Klavikula lateralinin alt tarafının eklem kapsül bütünlüğünde minimal bozulma oluşturarak akromiyon ile aynı seviyeye gelecek şekilde eksizyonu uzun dönemde akromiyoklaviküler eklem semptomları oluşturmamaktadır.

Anahtar sözcükler: Akromiyoklaviküler eklem; akromioplasti; artroskopi; eşplanlama; omuz; sıkışma.

Ulus Travma Acil Cerrahi Derg 2018;24(3):274-277 doi: 10.5505/tjtes.2017.6II78 